\title{
Pseudomonas extremaustralis sp. nov., a Poly(3-hydroxybutyrate) Producer Isolated from an Antarctic Environment
}

\author{
Nancy I. López · M. Julia Pettinari • \\ Erko Stackebrandt $\cdot$ Paula M. Tribelli • \\ Markus Põtter · Alexander Steinbüchel · \\ Beatriz S. Méndez
}

Received: 2 June 2009/Accepted: 20 July 2009/Published online: 18 August 2009

(C) Springer Science+Business Media, LLC 2009

\begin{abstract}
A Gram-negative, mobile, rod-shaped, nonspore-forming bacterium (strain 14-3 $3^{\mathrm{T}}$ ) was isolated from a temporary pond in Antarctica. On the basis of 16S rRNA gene sequence similarity, strain $14-3^{\mathrm{T}}$ was shown to belong to the genus Pseudomonas sensu stricto. Physiological and biochemical tests supported the phylogenetic affiliation. Strain $14-3^{\mathrm{T}}$ is closely related to Pseudomonas veronii DSM $11331^{\mathrm{T}}$, sharing $99.7 \%$ sequence similarity. DNADNA hybridization experiments between the two strains showed only moderate reassociation similarity (35.1\%). Tests for arginine dihydrolase and nitrate reduction were positive, while those for denitrification, indol production, glucose acidification, urease, B-galactosidase, esculin, caseine and gelatin hydrolysis were negative. Growth of this bacterium occurred in a range from 4 to $37^{\circ} \mathrm{C}$ but not at $42^{\circ} \mathrm{C}$. It accumulated poly (3-hydroxybutyrate) when grown on sodium octanoate medium. Strain $14-3^{\mathrm{T}}$ therefore represents the type strain of a new species, for which the name Pseudomonas extremaustralis sp. nov. is proposed. The
\end{abstract}

The GenBank/EMBL/DDBJ accession number for the 16S rRNA gene sequence of strain $14-3^{\mathrm{T}}$ is AJ583501.

N. I. López $(\varangle)$ · M. J. Pettinari · P. M. Tribelli · B. S. Méndez Dpto. de Qca. Biológica, Facultad de Ciencias Exactas y Naturales, Universidad de Buenos Aires, Buenos Aires, Argentina

e-mail: nan@qb.fcen.uba.ar

E. Stackebrandt

DSMZ-Deutsche Sammlung von Mikroorganismen

und Zellkulturen, Braunschweig, Germany

M. Põtter · A. Steinbüchel

Institut für Molekulare Mikrobiologie und Biotechnologie der

Westfälischen Wilhelms-Universität Münster, Münster,

Germany type strain $14-3^{\mathrm{T}}$ has been deposited as DSM $17835^{\mathrm{T}}$ and as CIP $109839^{\mathrm{T}}$.

\section{Introduction}

The genus Pseudomonas, first described by Migula in 1894 [26], currently comprises a large number of species. Over the years, many studies have been conducted on this genus to differentiate it from other genera and to define intrageneric clusters $[2,25]$. Due to their metabolic versatility and ubiquity in nature, new species of the genus inhabiting different kinds of environments are constantly described, including species from extreme areas such as Antarctica [8, 10, 22, 24, 30, 32].

Pseudomonas sp. 14-3 is a strain isolated from a temporary pond in Antarctica. This strain shows a high heat and oxidative stress resistance [3] and increased cold tolerance [6] in association with its high capacity of accumulate large amounts of polyhydroxybutyrate (PHB), the best known polyhydroxyalkanoate (PHA). We have previously performed several genetic studies regarding PHA metabolism of this strain $[4,5]$. In this work, we characterized strain 14-3. Polyphasic taxonomy revealed that it represents a novel species for which the name Pseudomonas extremaustralis sp. nov. is proposed.

\section{Methods}

Sampling Area and Isolation Procedure

Samples from several Antarctic habitats at Cierva Point, located on the Danco Coast on the west side of the Antarctic Peninsula, at $64^{\circ} 09^{\prime} \mathrm{S}, 60^{\circ} 57^{\prime} \mathrm{W}$, were screened for 
PHA producing bacteria. Samples from this area were taken during cruise CAV95 from Instituto Antártico Argentino (IAA) in 1995. During a study devised for the detection of spore-forming PHA producers, water samples from a temporary water body were heated at $80^{\circ} \mathrm{C}$ during $10 \mathrm{~min}$ and then plated on nutrient agar (NA) supplemented with $30 \mathrm{mM}$ sodium octanoate and incubated at $30^{\circ} \mathrm{C}$ as described [3] . PHA accumulation was detected by microscopic Nile Blue stain [28] and verified by gas chromatography [9]. Strain $14-3^{\mathrm{T}}$ was chosen because of its high PHB production (80\% polymer/dry weight).

\section{Morphological and Biochemical Characterization}

Bacterial cultures in different growth phases were used to check bacterial shape and motility by microscopy. Cells were stained according to the classical Gram procedure. Several biochemical determinations including catalase, amylase, glycerol and L-phenylalanine utilization, casein hydrolysis and denitrification were performed as individual tests. Oxidase testing was assayed using commercial disks (Britania, Argentina). Other biochemical tests were carried out using API 20 NE (bioMérieux, Argentina).

\section{Phylogenetic Analysis}

DNA extraction and PCR amplification were performed as described by Rainey and Stackebrandt [29]. The 16S rRNA gene was amplified using a universal primer set corresponding to positions 8-27 (forward primer) and 1505-1525 (reverse primer) based on Escherichia coli sequence [29]. The sequence of the $16 \mathrm{~S}$ ribosomal RNA gene was determined using a SeqiTherm Long-Read cycle sequencing kit (Epicentre Technologies, Madison, WI, USA) in a model 4000L semiautomatic DNA sequencer (LI-COR). The nucleotide sequence of the 16S rRNA gene of strain 14-3 ${ }^{\mathrm{T}}$ is available under EMBL Nucleotide Sequence Database accession number AJ583501. The 16S rRNA gene sequence was initially analyzed by using BLAST program (http://www.ncbi.nlm.nih.gov/blast) [1]. Multiple alignment of sequences was performed using CLUSTAL X [34]. The phylogenetic tree was constructed using the neighborjoining method of Saitou and Nei [31], and checked by UPGMA and maximum parsimony methods all included in MEGA 3 package [23]. The tree topology was tested by bootstrap analysis of 1000 resamplings. Pseudomonas aeruginosa was used as an outgroup.

\section{DNA-DNA Hybridization}

DNA was isolated using a French pressure cell (Thermo Spectronic, Rochester, NY, USA) and was purified by hydroxyapatite chromatography as described by Cashion et al. [11]. DNA-DNA hybridization was carried out as described by De Ley et al. [12], with the modifications of Huss et al. [17] and Escara and Hutton [16], using a model Cary 100 Bio UV/VIS-spectrophotometer equipped with a Peltier-thermostated $6 \times 6$ multicell changer and a temperature controller with in situ temperature probe (Varian, Victoria, Australia).

\section{Fatty Acids Profile}

Fatty acids were extracted and analyzed [27] according to the standard protocol of the Microbial Identification System (MIDI; Microbial ID). Extracts were analyzed using a Hewlett Packard model HP6890A gas chromatograph equipped with a flame ionization detector as described by Kämpfer and Kroppenstedt [19].

\section{Results and Discussion}

The phenotypic characterization showed this isolate to be a Gram-negative, non-sporulating bacterium with straight and mobile rods. It grew on E minimal medium [35], presented a non-fermentative metabolism on a wide range of sugars, was oxidase-positive and synthesized a fluorescent pigment when grown on King B medium [21]. Growth of this bacterium was observed from 4 to $37^{\circ} \mathrm{C}$ but not at $42^{\circ} \mathrm{C}$. No reaction was observed for indol production, glucose acidification, urease, ß-galactosidase, esculin, caseine, lecithin, starch and gelatin hydrolysis, whilst arginine dihydrolase and nitrate reduction were positive. The strain was capable of utilizing D-glucose, L-arabinose, D-mannitol, potassium gluconate, glycerol, capric acid, adipic acid, malic acid and trisodium citrate. D-Mannose, $\mathrm{N}$-acetyl-glucosamine, L-phenylalanine and D-maltose were not utilized. The phenotypic studies showed that the isolate displayed characteristics consistent with those described for the genus Pseudomonas.

Comparison of the 16S rRNA gene sequence of strain 14- $3^{T}$ with those of other type strains of Pseudomonas showed the highest sequence similarity with Pseudomonas veronii DSM $11331^{\mathrm{T}}$ (99.7\% identity), followed by Pseudomonas trivialis DSM $14937^{\mathrm{T}}(99.6 \%$ identity) and Pseudomonas poae DSM $14936^{\mathrm{T}}$ (99.5\% identity). Comparison of phenotypic characteristics that differentiate strain $14-3^{\mathrm{T}}$ from $P$. veronii, $P$. poae and $P$. trivialis are shown in Table 1. Strain 14-3 $3^{\mathrm{T}}$ exhibited minor sequence similarity with the Antarctic isolates, Pseudomonas antarctica DSM $15318^{\mathrm{T}}$ (98.7\%), Pseudomonas meridiana CMS $38^{\mathrm{T}}$ (98.6\%), Pseudomonas proteolytica CMS $64^{\mathrm{T}}$ (98.2\%) and Pseudomonas guineae LMG $24016^{\mathrm{T}}$ (95. 3\%), and differed from these species in several phenotypic characters (Table 1). Strain $14-3^{\mathrm{T}}$ and $P$. veronii presented 
Table 1 Phenotypic characteristics that differentiate strain $14-3^{\mathrm{T}}$ from other closely phylogenetically related and Antarctic species

\begin{tabular}{|c|c|c|c|c|c|c|c|c|}
\hline Characteristic & 1 & 2 & 3 & 4 & 5 & 6 & 7 & 8 \\
\hline Gelatin hydrolysis & - & $\mathrm{D}$ & $\mathrm{D}$ & $\mathrm{D}$ & - & - & + & - \\
\hline Arginine dihydrolase & + & + & - & - & - & - & - & - \\
\hline Esculin hydrolysis & - & - & + & + & - & - & - & - \\
\hline Urease & - & $\mathrm{D}$ & NR & NR & + & $\mathrm{W}$ & - & - \\
\hline PHB production & + & - & NR & NR & - & - & - & NR \\
\hline Production of fluorescent pigment on King's B medium & + & + & + & + & - & + & NR & - \\
\hline Oxidase & + & + & W & $\mathrm{W}$ & + & + & + & + \\
\hline Nitrate reduction & + & + & - & - & + & + & + & - \\
\hline Denitrification & - & + & - & - & NR & NR & NR & - \\
\hline \multicolumn{9}{|l|}{ Utilization of } \\
\hline D-Mannose & - & + & + & + & + & + & + & - \\
\hline$N$-Acetyl-glucosamine & - & $\mathrm{D}$ & $\mathrm{D}$ & $\mathrm{D}$ & NR & NR & NR & - \\
\hline D-Phenylalanine & - & + & - & - & NR & NR & + & NR \\
\hline
\end{tabular}

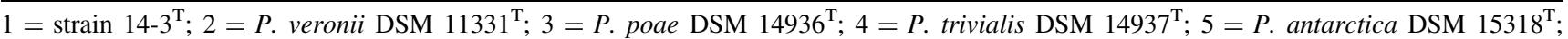
$6=P$. meridiana CMS $38^{\mathrm{T}} ; 7=P$. proteolytica CMS $64^{\mathrm{T}} ; 8=P$. guineae $\mathrm{LMG} 24016^{\mathrm{T}}$ ). Data were obtained in this and other studies $[7,8,15$, $18,30]$

$D$ reaction differs among strains, $N R$ not reported, $W$ weakly positive

negative esculin hydrolysis, positive arginine dihydrolase and strong (highly positive) oxidase reaction. Multiple alignment of rRNA gene sequences from strain $14-3^{\mathrm{T}}$ and other closely related type strains (31 type strains with identity higher than 95\%) was used to construct a phylogenetic tree. The resulting tree (Fig. 1) confirmed that strain $14-3^{\mathrm{T}}$ is a member of the genus Pseudomonas closely related to members of the fluorescent group as defined by Anzai et al. [2] . However, strain $14-3^{\mathrm{T}}$ did not form a robust clade with other Pseudomonas which had close percentage of sequence similarity (Fig. 1). A similar result was observed for $P$. veronii which, according to the present tree and previously published data [7, 18, 30], neither formed a robust clade with its closest relatives (Fig. 1).

The comparison of 16S rRNA gene sequences and the phenotypic characterization showed that $P$. veronii DSM $11331^{\mathrm{T}}$ is the closest relative to strain $14-3^{\mathrm{T}}$. Therefore, we determined the genomic relatedness between strain $14-3^{\mathrm{T}}$ and $P$. veronii DSM $11331^{\mathrm{T}}$, by the spectrophotometric DNA-DNA reassociation method. The resulting reassociation value of $35.1 \%$ was sufficiently low to separate them into two different genospecies. We also compared the fatty acid profile between strain $14-3^{\mathrm{T}}$ and $P$. veronii DSM $11331^{\mathrm{T}}$. Unsaturated $\mathrm{C}_{16: 1 \mathrm{~m}} 7 \mathrm{c}$ was the dominant fatty acid in the cell wall of strain 14-3 ${ }^{\mathrm{T}}$ (Table 2). Comparison of the fatty acid profile of both strains revealed a similar composition with mainly quantitative differences (Table 2).

Strain 14-3 $3^{T}$ accumulates PHB using octanoate as sole carbon source, but not when grown in medium containing glucose. It was shown that PHB accumulation confers high heat tolerance to this strain [3]. This fact could explain its unexpected isolation by a method unsuitable for the members of this genus (heating at $80^{\circ} \mathrm{C}$ under experiments for the detection of spore-former bacteria). Genetic analysis demonstrated that strain $14-3^{T}$ has a complete PHB biosynthesis cluster containing genes phaR, phaA, phaB and phaC and that impaired PHB production from glucose is due to a defective phaA gene [4]. These genes are located within a genomic island that also contains other genes probably related with its adaptability to Antarctic environments [5]. Inability of PHB-negative mutants to grow and survive under low-temperature conditions constitutes an evidence of the relevance of PHB genes for adaptability to cold environments [6]. According to data available in the literature [15] and analysis performed in our laboratory using glucose and sodium octanoate as carbon sources, $P$. veronii, the closest phylogenetic relative of strain $14-3^{\mathrm{T}}$, does not accumulate this polymer (data not shown). Strain $14-3^{\mathrm{T}}$ accumulated PHB up to $70-80 \%$ of its cell dry weight when grown on sodium octanoate [3, 4]. PHB production is a rare characteristic among Pseudomonas species, which usually accumulate PHA composed by medium-chain-length monomers when grown on fatty acids or carbohydrates [13, 33], and it has been proposed as an useful negative taxonomic criterion to differentiate bacterial species at the genus level [20]. However, species of the so-called "P. oleovorans group" produce PHB during cultivation on octanoate [14]. Pseudomonas sp. 14-3 is not phylogenetically related to species of this group.

As strain $14-3^{\mathrm{T}}$ shows sufficient phenotypic differences and moderate DNA-DNA similarity to its closest relative, 


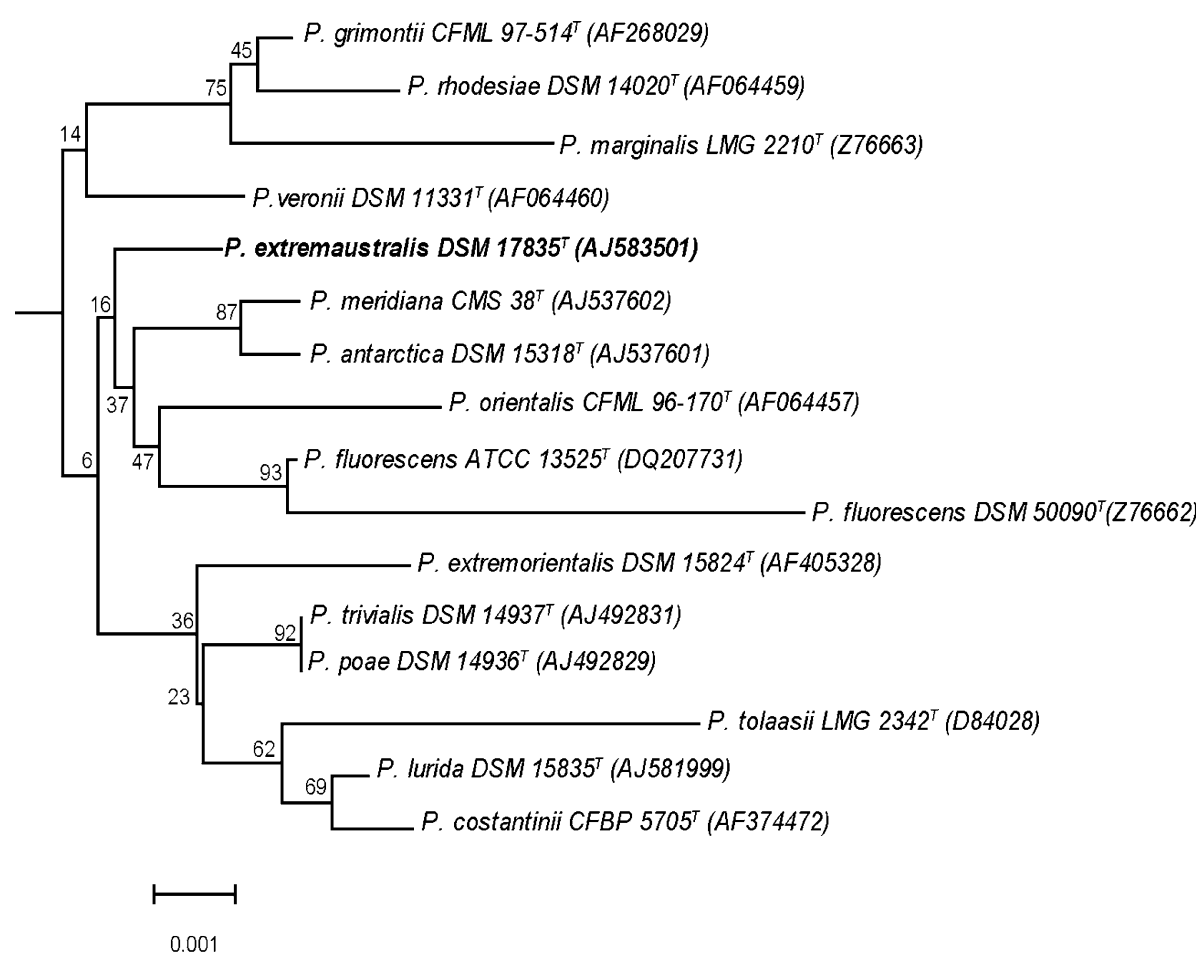

Fig. 1 Phylogenetic tree obtained by neighbor-joining analysis of $16 \mathrm{~S}$ rRNA gene sequences, showing the position of the Antarctic isolate 14$3^{\mathrm{T}}$ among neighboring species of the genus Pseudomonas. Percentages at nodes are levels of bootstrap support based on neighbor-joining analyses of 1000 re-sampled datasets. P. aeruginosa DSM 50071 (X06684) was used as outgroup (not shown). Bar 0.001 substitutions per

Table 2 Cellular fatty acid compositions $(\%)$ of strain $14-3^{\mathrm{T}}$ and $P$. veronii DSM $11331^{\mathrm{T}}$

\begin{tabular}{lcc}
\hline Fatty acids & Strain $14-3$ & $\begin{array}{l}\text { P. veronii } \\
\text { DSM } 11331^{\mathrm{T}}\end{array}$ \\
\hline $\mathrm{C}_{10: 0}$ & 0.15 & 0.18 \\
$\mathrm{C}_{10: 0} 3 \mathrm{OH}$ & 3.63 & 3.29 \\
$\mathrm{C}_{12: 0}$ & 2.66 & 2.39 \\
$\mathrm{C}_{12: 0} 2 \mathrm{OH}$ & 4.60 & 4.32 \\
$\mathrm{C}_{12: 0} 3 \mathrm{OH}$ & 3.84 & 3.48 \\
$\mathrm{C}_{14: 0}$ & 0.43 & 0.69 \\
$\mathrm{C}_{16: 1 \varpi} 7 \mathrm{c}$ & 37.53 & 31.45 \\
$\mathrm{C}_{16: 0}$ & 29.49 & 27.96 \\
$\mathrm{C}_{17: 0}$ & 0.15 & - \\
$\mathrm{C}_{17: 0}$ cyclo & 1.60 & 3.58 \\
$\mathrm{C}_{18: 1 \varpi} 7 \mathrm{c}$ & 15.09 & 20.80 \\
$\mathrm{C}_{18: 0}$ & 0.49 & 0.83 \\
$\mathrm{C}_{11 \text { methyl } 18: 1 \varpi \mathrm{c}}$ & 0.11 & 0.27 \\
$\mathrm{C}_{19: 0}$ cyclo $8 \mathrm{c}$ & - & 0.56 \\
\hline
\end{tabular}

Empty fields (-) indicate that fatty acids were not detected

P. veronii DSM $11331^{\mathrm{T}}$, we propose a new species, Pseudomonas extremaustralis sp. nov., with the type strain $14-3^{\mathrm{T}}\left(\mathrm{DSM} 17835^{\mathrm{T}}=\mathrm{CIP} 109839^{\mathrm{T}}\right)$. nucleotide position. The accession number of each reference species (DDBJ/EMBL/GenBank) is shown in parenthesis. $L M G$ The Belgian Co-ordinated Collections of Microorganisms, $C F B P$ Collection Française des Bactéries Phytopathogènes, $C F M L$ Collection de la Faculté de Médicine de Lille, ATCC American Type Culture Collection, DSM Deutsche Sammlung von Mikroorganismen und Zellkulturen

Description of $P$. extremaustralis sp. nov.

Pseudomonas extremaustralis (ex.tre.m.aus.tra' lis L. masc.adj. extrěmus furthest end, utmost point; L. fem. adj. australis austral, Southern; N.L. fem. adj. extremaustralis from the extreme South, the region of isolation, i.e. Far Southern Antarctica).

Cells are motile, non-spore-forming rods. Gram-negative, oxidase-positive, catalase-positive showing an oxidative metabolism. It produces fluorescent pigment on King B medium. Growth on nutrient agar plates occurs at 4 $37^{\circ} \mathrm{C}$ but not at $42^{\circ} \mathrm{C}$. Colonies on this medium are smooth, circular and non-pigmented. PHB is accumulated using sodium octanoate as carbon source. Tests for indol production, glucose acidification, urease, B-galactosidase, esculin, caseine, lecithin, starch and gelatin hydrolysis are negative, whilst arginine dihydrolase and nitrate reduction are positive. Negative for denitrification. The strain utilizes D-glucose, L-arabinose, D-mannitol, potassium gluconate, glycerol, capric acid, adipic acid, malic acid and trisodium citrate. D-Mannose, $\mathrm{N}$-acetyl-glucosamine, L-phenylalanine and D-maltose are not utilized. The fatty acid profile is indicated in Table 2. 
Isolated from a temporary water pond in Antarctica $\left(64^{\circ} 09^{\prime} \mathrm{S}, 60^{\circ} 57^{\prime} \mathrm{W}\right)$. The type strain is CT14-3 ${ }^{\mathrm{T}}$ (= DSM $17835^{\mathrm{T}}=$ CIP $109839^{\mathrm{T}}$ ).

Acknowledgments We thank Dr. Rubén Quintana for collecting Antarctic samples, Sandra Kohaus for technical assistance and Frank Reinecke for help during phylogenetic tree analysis. This work was supported by grants from UBA and CONICET. M.J.P., N.I.L. and B.S.M. are career investigators from CONICET. P.M.T. has a graduate student fellowship from CONICET.

\section{References}

1. Altschul SF, Madden TL, Schaffer AA, Zhang J, Zhang Z, Miller W, Lipman DJ (1997) Gapped BLAST and PSI-BLAST: a new generation of protein database search programs. Nucl Acids Res 25:3389-3402

2. Anzai Y, Kim H, Park JY, Wakabayashi H, Oyaizu H (2000) Phylogenetic affiliation of the pseudomonads based on 16S rRNA sequence. Int J Syst Bacteriol 50:1563-1589

3. Ayub ND, Pettinari MJ, Ruiz JA, López NI (2004) A polyhydroxybutyrate-producing Pseudomonas sp. isolated from Antarctic environments with high stress resistance. Curr Microbiol 49:170-174

4. Ayub ND, Pettinari MJ, Méndez BS, López NI (2006) Impaired polyhydroxybutyrate biosynthesis from glucose in Pseudomonas sp. 14-3 is due to a defective beta-ketothiolase gene. FEMS Microbiol Lett 264:125-131

5. Ayub ND, Pettinari MJ, Méndez BS, López NI (2007) The polyhydroxyalkanoate genes of a stress resistant Antarctic Pseudomonas are situated within a genomic island. Plasmid 58:240-248

6. Ayub ND, Tribelli PM, López NI (2009) Polyhydroxyalkanoates are essential for maintenance of redox state in the Antarctic bacterium Pseudomonas sp. 14-3 during low-temperature adaptation. Extremophiles 13:59-66

7. Behrendt U, Ulrich A, Schumann P (2003) Fluorescent pseudomonads associated with the phyllosphere of grasses; Pseudomonas trivialis sp. nov., Pseudomonas poae $\mathrm{sp}$. nov. and Pseudomonas congelans sp. nov. Int $\mathrm{J}$ Syst Evol Microbiol 53:1461-1469

8. Bozal N, Montes MJ, Mercadé E (2007) Pseudomonas guineae sp. nov., a novel psychrotolerant bacterium from an Antarctic environment. Int J Syst Evol Microbiol 57:2609-2612

9. Braunegg G, Sonnleitner B, Lafferty RM (1978) A rapid gas chromatographic method for the determination of poly-ßhydroxybutyric acid in microbial biomass. Eur J Appl Microbiol Biotechnol 6:29-37

10. Bruni V, Gugliandolo C, Maugeri T, Allegra A (1999) Psychrotrophic bacteria from a coastal station in the Ross Sea (Terra Nova Bay, Antarctica). New Microbiol 22:357-363

11. Cashion P, Hodler-Franklin MA, McCully J, Franklin M (1977) A rapid method for base ratio determination of bacterial DNA. Anal Biochem 81:461-466

12. De Ley J, Cattoir H, Reynaerts A (1970) The quantitative measurement of DNA hybridization from renaturation rates. Eur $\mathbf{J}$ Biochem 12:133-142

13. de Smet MJ, Eggink G, Witholt B, Kingma J, Wynberg H (1983) Characterization of intracellular inclusions formed by Pseudomonas oleovorans during growth on octane. J Bacteriol 154:870-878

14. Diard S, Carlier JP, Ageron E, Grimont PAD, Langlois V, Guerin P, Bouvet OMM (2002) Accumulation of Poly(3-hydroxybutyrate) from octanoate in different Pseudomonas belonging to the rRNA homology group I. Syst Appl Microbiol 25:183-188

15. Elomari M, Coroler L, Hoste B, Gillis M, Izard D, Leclerc H (1996) DNA relatedness among Pseudomonas strains isolated from natural mineral waters and proposal of Pseudomonas veronii sp. nov. Int J Syst Bacteriol 46:1138-1144

16. Escara JF, Hutton JR (1980) Thermal stability and renaturation of DNA in dimethyl sulfoxide solutions: acceleration of the renaturation rate. Biopolymers 19:1315-1327

17. Huss VAR, Festl H, Schleifer KH (1983) Studies on the spectrophotometric determination of DNA hybridization from renaturation rates. Syst Appl Microbiol 4:184-192

18. Ivanova EP, Gorshkova NM, Sawabe T, Hayashi K, Kalinovskaya NI, Lysenko AM, Zhukova NV, Nicolau DV, Kuznetsova TA, Mikhailov VV, Christen R (2002) Pseudomonas extremorientalis sp. nov., isolated from drinking water reservoir. Int J Syst Evol Microbiol 52:2113-2120

19. Kämpfer P, Kroppenstedt RM (1996) Numerical analysis of fatty acid patterns of coryneform bacteria and related taxa. Can $\mathrm{J}$ Microbiol 42:989-1005

20. Kessler B, Palleroni NJ (2000) Taxonomic implications of synthesis of poly- $\beta$-hydroxybutyrate and other poly- $\beta$-hydroxyalkanoates by aerobic pseudomonads. Int J Syst Evol Microbiol 50:711-713

21. King EO, Ward MK, Raney DE (1954) Two simple media for the demonstration of pyocyanin and fluorescein. J Lab Clin Med 44:301-307

22. Kriss AE, Mitskevich IN, Rozanova EP, Osnitskaia LK (1976) Microbiological studies of the Wanda Lake (Antarctica). Mikrobiologiya 45:1075-1081

23. Kumar S, Tamura K, Nei M (2004) MEGA3: integrated software for Molecular Evolutionary Genetics Analysis and sequence alignment. Brief Bioinform 5:150-163

24. Maugeri TL, Gugliandolo C, Bruni V (1996) Heterotrophic bacteria in the Ross Sea (Terra Nova Bay, Antarctica). New Microbiol 19:67-76

25. Moore ERB, Mau M, Arnscheidt A, Bottger EC, Hutson RA, Collins MD, Van De Peer Y, De Wachter R, Timmis KN (1996) The determination and comparison of the 16S rRNA gene sequences of species of the genus Pseudomonas (sensu stricto) and estimation of the natural intrageneric relationships. Syst Appl Microbiol 19:478-492

26. Migula W (1894) Über ein neues System der Bakterien. Arb Bakteriol Inst Karlsruhe 1:235-238

27. Miller LT (1982) A single derivatization method for bacterial fatty acid methyl esters including hydroxy acids. J Clin Microbiol 16:584-586

28. Ostle A, Holt JG (1982) Nile Blue A as a fluorescent stain for poly-hydroxybutyrate. Appl Environ Microbiol 44:238-241

29. Rainey FA, Stackebrandt E (1993) 16S rDNA analysis reveals phylogenetic diversity among the polysaccharolytic clostridia. FEMS Microbiol Lett 113:125-128

30. Reddy GSN, Matsumoto GI, Schumann P, Stackebrandt E, Shivaji S (2004) Psychrophilic pseudomonads from Antarctica: Pseudomonas antarctica sp. nov., Pseudomonas meridiana sp. nov. and Pseudomonas proteolytica sp. nov. Int J Syst Evol Microbiol 54:713-719

31. Saitou N, Nei M (1987) The neighbor-joining method: a new method for reconstructing phylogenetic trees. Mol Biol Evol 4:406-425

32. Shivaji S, Vijama Bhanu N, Aggarwal RK (1989) Isolation and identification of Pseudomonas spp. from Schirmacher Oasis, Antarctica. Appl Environ Microbiol 55:767-770

33. Timm A, Steinbüchel A (1990) Formation of polyesters consisting of medium-chain-length 3-hydroxyalkanoic acids from 
gluconate by Pseudomonas aeruginosa and other fluorescent pseudomonads. Appl Environ Microbiol 56:3360-3367

34. Thompson JD, Gibson TJ, Plewniak F, Jeanmougin F, Higgins DG (1997) The CLUSTAL_X windows interface: flexible strategies for multiple sequence alignment aided by quality analysis tools. Nucleic Acids Res 25:4876-4882
35. Vogel HJ, Bonner BN (1956) Acetyl-ornithinase of Escherichia coli: partial purification and some properties. J Biol Chem 218:97-106 